\title{
THE BIOLOGIC POINT OF VIEW.
}

\section{By Artitur Galette Clement. \\ Inspector of Schools. The University of the State of New York, Albany.}

One of the aims of an elementary course in biology is to give students some understanding of the essential functions carried on by all living things. When students comprehend this aim, they realize that they are studying biology and not three separate subjects, physiology, botany and zoology. They perceive how the different phases of the science are unified, and acquire the biologic point of view.

Paradoxical as the statement may seem, the teacher with the best university training is sometimes unsuccessful in giving instruction to first year high school students because he uses too fully the inductive method. By endeavoring to conform too closely to this method, he fails to secure the immediate interest of his students and does not make clear to them the unity of the subject.

In teaching biology to students in the first year of the high school, any instructor will find it advantageous to employ at the beginning of the course the vocabulary already in the minds of the students rather than to introduce the subject by the use of some topic like the structure of the cell, which requires knowledge of new terms; and he will undoubtedly meet with more ready response on the part of the students if the experimental work is begun with objects familiar to them rather than with a series of unfamiliar structures.

At the beginning of this study much time may be gained by ascertaining what physiologic facts the students have already acquired from observation of their own bodies and from their own experiences. This implies that the study shall begin, not with microscopic examination of protozoa and algae, but with the object. with which the students are most familiar, the human body.

An elementary course in biology is best approached by placing emphasis on function rather than on structure. Young students will grasp the idea of function much more readily by observing as fair as possible the physiologic processes of the human body, than by considering the properties of protoplasm.

If students have been properly instructed in physiology during their grammar school course, they will already know the meaning of the word function and will be able to name the essential 
functions of the body. Unfortunately, however, owing to the desultory instruction given in physiology in pre-academic grades, the majority of students are not able to mention all the essential functions necessary to life. Let any teacher who doubts this ask the members of his class to enumerate these and I think he will be convinced of the accuracy of this statement.

First, then, students should learn as much as possible about the functions necessary for daily life by the consideration of the life processes of the body. If skilfully directed and questioned by the teacher, they will discover the following: motion, respiration, circulation of blood, excretion and sensation, all physiologic phenomena. The nature of absorption and of digestion can be shown by experiments, and the idea of assimilation taught deductively. If reproduction, which is necessary for the continuance of the race, is added to this list, the students will have in mind the essential physiologic functions of the human body. They will call this study physiology.

The study of an animal, preferably a frog, should then be carefully made. In this study the fact that its life functions are the same as those of the human body should be developed as the various parts are examined and their similarity to organs of the human body explained. The students will call this study zoölogy.

The study of the animal should immediately be followed by the study of the plant as a whole, e. g., a bean seedling. In this study the students should learn by experiments, as far as possible, that the life processes of the plant are similar to those of the frog and of man. The students will call this subject botany.

The skilful teacher never neglects to base his instruction on knowledge already acquired by the students. The latter know that plants as well as man and animals require food. They know also that plants make food for man and animals, but they do not always understand that green plants make the food for their own use and store it in seeds, leaves and roots.

By simple experiments students are easily convinced that plants show motion and sensation in response to light. Some have already observed in the field or the garden that plants have these attributes. By other experiments they may be shown that plants use oxygen and excrete carbonic acid gas in respiration. The excretion of moisture is also easily demonstrated. The experiment to show the movement of fluid as it rises in stems always interests students. The fact of reproduction they never question. All have probably sown seeds and observed their growth. 
In the germination and growth of seeds the stored food is digested, absorbed, passed from cell to cell and assimilated. Thus nutrition is accomplished in plants the same as in man and in animals. These facts should be explained and, as far as possible, made clear by demonstrations.

The time has now arrived when the teacher should explain that, since the functions necessary to life are the same in plants, animals and man, the subject matter discussed is really all one study, namely biology, this word meaning a discourse on life.

The following table will give a graphic representation of the discussion suggested:

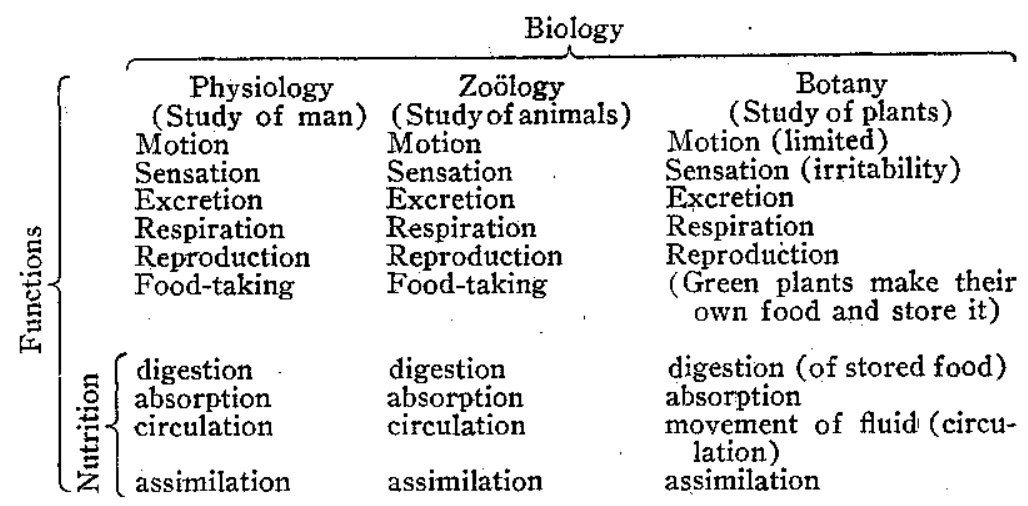

If a teacher will develop a table similar to this one by the study of a frog or other higher animal and by the study of some common plant in comparison with man, emphasizing the idea of function, he will have little difficulty in establishing the biologic point of view in the minds of his students and will have the pleasure of seeing them grasp the idea of the unity of the living world comparatively early in the course of study.

\section{ALUMINUM FROM CLAY.}

Though new bauxite deposits are being found from time to time, there is considerable interest in the preparation of pure alumina from clay or other silicate minerals. As soon as a process for the extraction of alumina from clay is put on a commercial basis, large quantities of low grade bauxite containing considerable admixtures of clay will become available as aluminum producers. According to the United States Geological Survey there is a large tonnage of such material associated with most of the southern Appalachian bauxite. 